\title{
The Necessity of Compiling a Learners' German- English Etymological Dictionary for Chinese Students
}

\section{Qu Changliang}

School of International Business, Dalian University of Foreign Languages, China

How to cite this paper: Qu, C. L. (2017). The Necessity of Compiling a Learners' German-English Etymological Dictionary for Chinese Students. The Educational Review, USA, 1(4), 101-106.

http://dx.doi.org/10.26855/er.2017.04.004

Corresponding author: Changliang Qu, Ph.D., School of International Business, Dalian University of Foreign Languages, Dalian, China.

\begin{abstract}
Although historic phonology sounds highly theoretical, its principles are actually applicable in current language teaching practice in China. While students who major in English are expected to choose a second foreign language as a required course, Western European languages like German, French and Spanish are usually their most frequent choice due to their formal similarity and historical proximity to English. But unlike French that has exported a large vocabulary to English, the cognates between German and English are more typically reflexes from a shared ancestral Germanic language than results of direct borrowing. As a result, in English vocabulary it is often more difficult to recognize a German cognate than a French one, because phonological and semantic evolution has concealed much of their formal similarity. Quite often, learners do not automatically benefit more from the fact that German and English belong to the same branch of the Germanic language family. Therefore, students who begin to learn German after they become advanced learners of English may need a new type of etymological dictionary that facilitate their learning. This dictionary is not merely designed for the "élite" students who will deepen in theoretical linguistics, but for a larger group of learners who intend to grasp more effectively the vocabulary of a second foreign language. The present paper aims to explore how historical phonology is applied in preparing such a dictionary and what etymological information should be presented in this dictionary.
\end{abstract}

Keywords

Cognates, Etymological dictionary, Historical phonology

\section{Introduction}

Etymological information, although usually forming an inseparable part in the entries of a dictionary for native speakers, is often considered unnecessary in a dictionary specially designed for learners of foreign languages. This partly explains the reason why etymological information is absent in many successful dictionaries of the latter type, like Oxford Advanced Learners' Dictionary of Current English and Longman Dictionary of Contemporary English. However, when learners are trying to learn a third language historically related to their second language that they have largely grasped, the need for such information manifestly arises for its role in vocabulary comparison between the second and the third language.

In China nearly all students who major in English language and literature are learners of a third language, since "the second foreign language" is a required course for both their undergraduate and graduate studies. Traditionally this course intends to offer them a better understanding of language structure, while nowadays grasping one more foreign language 
often becomes a skill that makes them more competitive in the job market. In practice, it is either French, or German, or Spanish that the students frequently choose to be their "second foreign language". An obvious reason for this choice is these languages' formal similarity and historical proximity to English, the language that they have grasp enough to produce positive transfer.

Based on historical linguistics, a comparison between German and English vocabulary is helpful for the students who have largely grasped English. But unlike French that has directly exported a large vocabulary to English, the cognates between German and English are more typically reflexes from a shared ancestral Germanic language than results of direct borrowing. Consequently in English vocabulary, it is often more difficult to recognize a German cognate than a French one, because phonological and semantic evolution has concealed much of their formal similarity. Quite often, learners do not automatically benefit more from the fact that German and English belong to the same branch of the Germanic language family. Therefore, the students who begin to learn German after they have become advanced learners of English may need a new type of etymological dictionary that facilitates their German learning.

Unfortunately, the etymological information is missing in the most frequently used learners' dictionaries in China. It is given in neither the locally compiled Deutsch-Chinesisches Wörterbuch, nor the imported Langenscheidts Großwörterbuch Deutsch als Fremdsprache. And traditional classics like Kluge's An Etymological Dictionary of the German Languages now look fairly intimidating to the average students. Therefore, it becomes necessary to compile a learners' German-English-Chinese etymological dictionary which is not merely designed for the "élite" students who will deepen in theoretical linguistics, but for a larger group of learners who intend to grasp more effectively the vocabulary of a second foreign language. In this concise and practical dictionary, the etymological comparison between the German and the English vocabulary should be conducted both phonologically and semantically. Chinese etymology will not be discussed in this dictionary, for Chinese is by no means related to these two languages genetically. But since the dictionary is designed for Chinese students who learn these two languages, it is necessary to translate the headwords of the entries into Chinese.

\section{Phonological Evolution as the Theoretic Basis for the Proposed Dictionary}

\subsection{The German Side of the Phonological Evolution}

An obvious necessity for compiling such a dictionary lies in the fact that the processes of phonological evolution on both the German side and the English side have long concealed the resemblance of the cognates. On the German side, compiling such a dictionary involves a revived interest in the "High German consonant shift", the phonological law familiarly known as the "second Germanic consonant shift" when compared to the Grimm's Law (the first Germanic consonant shift). This shift is highly visible in any basic German wordlist.

Classical works on historical linguistics typically describe the two or three core stages, sometimes plus a few other stages, of the evolutionary process that made the High German consonantal system distinguishable from those of the other Germanic languages and dialects. The earlier of the core stages, in which the three Germanic voiceless plosives /p, $\mathrm{t}, \mathrm{k} /$ became their correspondent fricatives /f, s, x/ or affricates /pf, ts/, is prevalent, although the differences in their vowels often conceal their resemblance. When the etymological information is available, the vague correspondence between the English-German cognates looks more straightforward. For example:

schlafen $(<$ OHG. slâffan $)-$ sleep $(<$ OE. slǣpan)

essen $(<$ OHG. ezzan $)-$ eat $(<$ OE. etan $)$

suchen $(<$ OHG. suohhan $)-\operatorname{seek}(<$ OE. sēcan $)$

Pfund $(<$ OHG. pfunt $)-$ pound $(<$ OE. pund $)$ 
Herz ( $<$ OHG. herza) - heart $(<$ OE. heorte)

Equally highly visible is a later stage, in which the three voiced plosives /b, d, g/ became voiceless in High German. This evolutionary mostly occurs at the coda position, but orthographically the pre-evolution spellings of the final consonants have remained, making this rule widely known as "Auslautverhärtung" (final-obstruent devoicing) in almost all the beginners' textbooks. Probably the only case of this stage that needs explanations is the initial German /t/ corresponding to the English initial /d/, e.g. tanzen (dance), Tür (door), trinken (drink) etc., since the historical devoicing did not happen to the initial German /b/ and /g/.

Old High German experienced other consonantal changes after the High German consonant shift. In the German-English vocabulary comparison, these more recent changes are reflected in the correspondence between German /b/ and English /f, v/, as well as that between German /d/ and English / $\theta, \mathrm{\partial} /$ :

Leben $(<$ OHG. lîb) - life $(<$ OE. līf $)$

oben $(<$ OHG. obana $)-$ over $(<$ OE. ufan $)$

durch $(<$ OHG. duruh $)-$ through $(<$ OE. purh)

da $(<$ OHG. dâr $)-$ there $(<$ OE. pǣr $)$

In all these examples, consonantal shifts to some extent have hidden the historical closeness of the cognates. But what makes them even more unrecognizable is the vocalic differences. In classical works on German or Germanic historical phonology, the evolution of the vowels from Old High German to Modern German is a profoundly complicated and thoroughly discussed issue (e.g. Helfenstein 1870, Wright 1907 etc.). However, a practical dictionary for learners may well circumvent this sophistication. In most of the cases, the vocalic evolutionary correspondences are not easy to explain smoothly. A lot of the cognates had already contained distinct vowels in the age of Old High German / Old English. In this case a description (rather than an explanation) is enough. For example:

gruß $(<$ OHG. gruo3) - great $(<$ OE. grētan $)$

hören $(<$ OHG. hôren $)-$ hear $(<$ OE. hȳran)

mehr $(<$ OHG. mêro $)-$ more $(<$ OE. māro)

tot $(<$ OHG. tôt $)-$ dead $(<$ OE. deād $)$

\subsection{The English Side of the Phonological Evolution}

The consonantal shifts took place not only on the German side, but on the English side. One of the most crucial change is the $/ \mathrm{g} />/ \mathrm{j}, \mathrm{w} /$ shift in Early Modern English that hide much of the resemblance of the German-English cognates in both pronunciation and spelling.

This shift is a cause for the resurgence of a new English diphthong system after the Old English diphthongs (ea, eo, ēa, ēo, eō etc.) had all disappeared during the transition to the Middle English (Jespersen 1909: 94). The new English diphthongs are combinations of vowels and $/ \mathrm{j} /$ or $/ \mathrm{w} /$ that shifted from $/ \mathrm{g} /$. These new diphthongs makes the English words look quite different from their German cognates that experienced no such change. In other words, these German cognates are much less recognizable. For example:

OE. æg, eg, $\overline{x g}>/ \mathfrak{x}(:) \mathrm{i} />/ \mathrm{ei} /$ :

day $(<$ OE. dæg $)-$ Tag $(<$ OHG. tag $)$

sail $(<$ OE. segel $)-$ Segel $(<$ OHG. segal)

OE. āw, āg $>/ \mathrm{o}: \mathrm{u} />/ \mathrm{\jmath u} /$ :

sow (< OE. sāwan) - säen (< OHG. sâen)

dough $(<$ OE. dāg $)-$ Teig $(<$ OHG. teig $)$ 
OE. aw, ag $>/ \mathrm{au} /$ :

thaw $(<$ OE. pawian $)-$ tauen $(<$ MHG. touwen $<$ OHG. douwen $)$

gnaw $(<$ OE. gnagan $)-$ nagen $(<$ OHG. gnagan $)$

Another wide-spread consonantal shift on the English side is the loss of /ç/ and /x/. The distribution of these two fricatives in Old and Middle English used to be the same as in German today: /ç/ appears after a front vowel and / $\mathrm{x} /$ after a back vowel. With the loss of the two fricatives in Early Modern English, the vowels before them experienced compensatory lengthening, making the Modern English pronunciation distinctive from that of their German cognates. However, since the now silent English gh is retained orthographically, the German cognates are not very difficult to recognize:

light $(<$ OE. lēoht $)-$ Licht $(<$ OHG. lioht $)$

right $(<$ OE. riht $)-$ recht $(<$ OHG. recht $)$

daughter $(<$ OE. dohter $)-$ Tochter $(<$ OHG. tohter $)$

high $(<$ OE. hēah $)-$ hoch $(<$ OHG. hôh $)$

In addition, compared with the consonantal system, the English vocalic shifts happened more drastically but more regularly. In the stage of Early Modern English, the Great Vowel Shift gradually occurred as a systematic set of changes that deformed the whole pattern of long vowels. But since this change took place after instead of before the orthographic customs became stabilized, it did not let the German-English cognates look highly different from each other.

\section{Semantic Information in the Word Entries}

\subsection{Faux-amis}

A vocabulary comparison between any two or more cognate languages has to face the problems caused by faux-amis, i.e. cognate words in these languages that look or sound highly similar, but differ or only partially overlap in meaning. Famous German-English cases include:

German aktuell, which means not only "actual" but "current", "relevant" or "topical";

German bekommen, which means "get" or "receive", and never "become";

German man, an indefinite pronoun that roughly equals to English "one", is never used as a noun meaning a male person. (The latter should be spelled as "Mann".)

Since all these faux-amis are historically related to their counterparts in English, they need a special precaution mark in the proposed learners' etymological dictionary.

\subsection{Lexeme Loss in Modern English}

When a German word looks extremely unfamiliar for those who have grasped much English, it is possible that the lexeme is only found in High German, or that it may be found in several other Germanic languages but not in English. The former case is represented by words like jetzt, while the latter case is represented by aber (<OHG. abur), which also appeared in Gothic as afar but not recorded in Old English or Old Norse (Walshe 1951: 2), though Kluge (1891: 2) reminded us of its relations to the Old English noun eafora "descendant". Such information is academically important, but not crucial in a learners' etymological dictionary.

What makes more sense is the German words that are related to some lost Old English lexemes replaced in the history either by French loans or by some other native lexemes. For example, the following German words, though unfamiliar in Modern English, were once active in Old English:

Beispiel (< OHG. bîspel) is a cognate of OE. spell (meaning "tale", one of the two components in "gospel"). In Middle 
English, it was replaced by the Old French word example;

drucken (< OHG. drucchen) is a cognate of OE. pryccan (meaning "oppress"). This lexeme also disappeared from the later English vocabulary while press, oppress and print are all from French;

Heirat (< OHG. hîrât) is a cognate of OE. hïred (meaning "household"). With the disuse of this lexeme in later English, both the newly introduced words family and marriage came from French.

Besides the above cases that Baugh and Cable (1993: 164) call "French words that poured into English", there are some other cases that the German-English cognate words were replaced by another Anglo-Saxon lexeme. For example:

heißen "be called" (< OHG. heizan) is a cognate of OE. hātan, now replaced by another native word call;

heute "today" ( $<$ OHG. hiutu) is a cognate of OE. heōdæg, now replaced by today.

A few Old English words still have reflexes in Modern English, but have turned into marginal words that are no longer as active as before. For example:

riechen "smell" $(<$ OHG. riohhan) is a cognate of OE. rēocan. Its descendant reek still exists in English today, but has fallen into the vocabulary of low frequency.

schmecken "taste" ( $<$ OHG. smecchen) is a similar case. Although it is a commonly used word in German, its cognate smack $(<$ OE. smæccan) sounds more literary than spoken.

All the above information deserves a serious place in the proposed learners' etymological dictionary.

\subsection{The Meaning Shifts in German-English Cognates}

When cognate languages evolve on separate paths, their cognate words may also diverge semantically, causing constant semantic shifts that sometimes make them unrecognizable.

Campbell (2008: 266-267) visualizes the process of meaning shift with a model that consists three stages: When the lowercased letter a stands for a word, its meaning may shift from "A" via "A" + "B" to merely "B".

If the shift happened in one language but did not happen in a language related to it, the meaning contrast, sometimes aided by phonological shift, can be strong enough to make the cognates unrecognizable. Furthermore, the cognates in different languages may experience different metaphors. Among the most frequently used German words, the following words have witnessed this type of semantic evolution. Unsurprisingly they seldom remind the learners of their English cognates:

klein "small” ( $<$ OHG. kleini “elegant") - clean $(<$ OE.clǣne $)$

laufen "run" (< OHG. hlauffan) - leap ( $<$ OE. hlēapan "run, leap")

Teil "part" $(<$ OHG. teil $)-$ deal $(<$ OE. dǣl $)$

Tisch "table" $(<$ OHG. tisc $)-$ dish $(<$ OE.disc $)$

Zug "train" $(<$ OHG. zug $)-$ tug $(<$ OE.tyge $)$

Some meaning shifts are not only semantic but morphological. For example, German verb faren ( $<$ OHG. faran) "ride" is a cognate of Old English verb faran "ride" which is no longer used in Modern English. However, fare, a noun derived from this verb is still commonly used today, with its meaning "the cost of a ride". Similarly, the German adjective krank "ill" (< MHG. kranc "weak") is a cognate of Old English cranc "feeble", an adjective that Kluge (1891: 191) labeled as "occur[ring] rarely". But cringan "writhe", the verb form of this lexeme, was much more common, evolving into cringe in Modern English. Without an appropriate etymological dictionary, it is almost impossible for learners today to expect that German krank and English cringe are cognates. 


\section{Conclusion and Sample Dictionary Entries}

To sum up this essay, we can take a look at how some of the above mentioned cognates will be processed as the word entries in this proposed dictionary. Since this dictionary is mainly designed for the Chinese learners who do not have much experience of being exposed to the Western-styled dictionaries of etymology, the information in each entry must be concise so that the dictionary will be easier to use, instead of intimidating the readers. Comparisons between etymological information between German and English cognates let the German words look more familiar, and the Chinese translations (with no etymological information) make the reading and comparing more effortless. Sample categories are exemplified as the following:

Entry Category 1\#, a cognate with a mere phonological shift:

schlafen (< OHG. slâffan) vi. schläft, schlief, hat geschlafen $\|$ sleep (< OE. slǣpan) vi. 睡觉

Entry Category 2\#, words with the risks of faux-amis:

bekommen (< OHG.bi + chuēman “come”) vi. bekam, hat bekommen $\|$ get, receive 得到, 获得 $\boldsymbol{\Delta}$ Never “become”.

Entry Category 3\#, the loss of an English lexeme:

Heirat (< OHG. hîrât) f. -, -en \| marriage n. 婚事 $\square$ cog. OE. hīred † "household".

Entry Category 4\#, with meaning shift:

klein (< OHG. kleini “elegant”) adj. \| small adj. 小的 $\square$ cog. OE. clǣne > clean.

Entry Category $5 \#$, with meaning shift together with morphological issues:

krank (< MHG. kranc “weak") adj. $\|$ ill adj. 患病的 $\square$ cog. OE. Cranc $\uparrow$ “feeble". $>$ OE. cringan “writhe, twist in pain" > cringe.

All the above sample entries direct to a principle in the preparation for a dictionary of this category: It should never be intended as an etymological dictionary by the standard of historical-comparative linguistic research. Therefore, priorities are given to the practical information that is essential to language learning, especially the information that allows the learners to benefit from the positive language transfer and to avoid the negative one. This intention makes it highly different from an etymological dictionary of the traditional sense.

\section{Acknowledgements}

This work is part of the Project "Theory of Phonological Evolution and Its Applications in English Vocabulary Teaching" supported by the 13th 5-Year Plan of Educational Science of Liaoning Province (No. JG17DB104) and part of the Project “A Study on Otto Jespersen's Ideas of Phonological Evolution (1886-1941)”, supported by National Social Science Foundation of China (No. 16BYY007).

\section{References}

Campbell, L. (2008). Historical Linguistics: An Introduction. Beijing: World Publishing Corporation, $252-282$.

Helfenstein, J. (1870). A Comparative Grammar of the Teutonic Languages. London: MacMillan, 26-95.

Jespersen, O. (1909/2014). A Modern English Grammar on Historical Principles. Vol. 1. Sound and Spelling. Beijing: World Publishing Corporation, 62-110.

Kluge, F. (1891). An Etymological Dictionary of the German Language. Trans. J. Davis. London: George Bell \& Sons, 2, 191.

Walshe, M. (1951). A Concise German Etymological Dictionary. London: Routledge \& Kegan Paul Ltd, 2.

Wright, J. (1907). Historical German Grammar. Vol.1. Phonology, Word-Formation and Accidence. London: Oxford University Press, 3966. 